
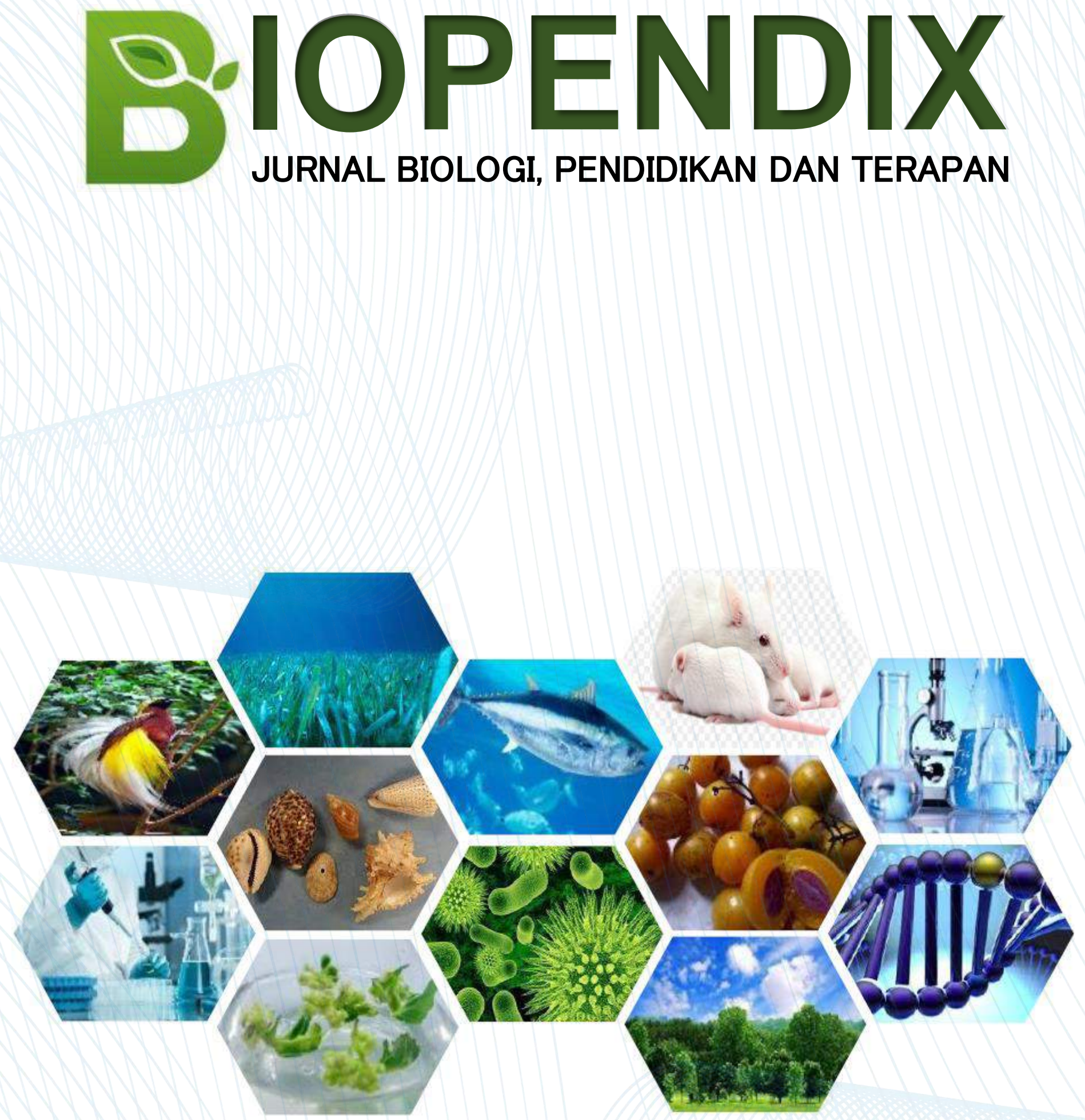

PUBLISHER BY:

BIOLOGY EDUCATION, UNPATTI AMBON - MALUKU 


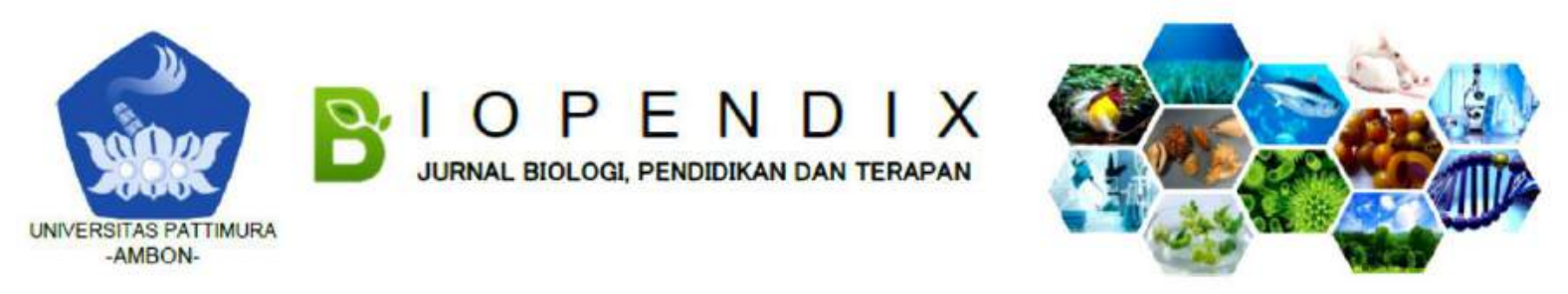

\title{
HUBUNGAN LINGKUNGAN SEBAGAI SUMBER BELAJAR DAN MOTIVASI MAHASISWA DALAM MENINGKATKAN MINAT DAN HASIL BELAJAR PADA MATA KULIAH MORFOLOGI TUMBUHAN DI SEKOLAH TINGGI KEGURUAN ILMU PENDIDIKAN ITA WOTU NUSA (STKIP-IWN) BULA
}

\author{
Dina Ismail ${ }^{1}$, Alwi Smith², M. Nur Matdoan² \\ ${ }^{1}$ Mahasiswa Program Studi Magister Pendidikan Biologi; \\ ${ }^{2}$ Dosen Program Studi Magister Pendidikan Biologi \\ *Corresponding author: Alwi Smith; e-mail: asmith.unpatti@gmail.com
}

\begin{abstract}
Background: Learning biology by utilizing the environment as a source of learning means using an environmental approach. An environmental approach is a learning strategy that is carried out by utilizing the environment as a source or teaching material. This study aims to determine the relationship of the environment as a source of learning and student motivation in increasing interest and learning outcomes in the Plant Morphology course at the Ita Wotu Nusa College of Education (STKIP-IWN) Bula.

Method: The method used in this study is the quasi-experimental method. The subjects of this study were all biology students in the third semester, totaling 30 students. Data collection techniques were carried out with initial tests, final tests and questionnaires. Data analysis techniques used in this study will be analyzed correlation test with the help of the IBM statistical program version 23.0 for windows.

Results: The results showed the relationship of $X 1$ (environment as a source of learning) with $Y 1$ (interest in learning) obtained sig. (2-tailed) $0.024<0.05$ with a correlation coefficient of 0.412 which means that both variables have a positive and significant relationship with the level moderate closeness. The relationship of $\mathrm{X} 1$ (environment as a source of learning) with $\mathrm{Y} 2$ (learning outcomes) obtained a value of sig. (2-tailed) $0.013<0.05$, with a correlation coefficient of 0.448 which means that the two variables have a positive and significant relationship with moderate levels of closeness. Relationship $\mathrm{X} 2$ (learning motivation) with Y1 (learning interest) sig. (2-tailed) $0.018<0.05$ with a correlation coefficient of 0.430 , which means that both variables have a positive and significant relationship with moderate levels of closeness. The relationship X2 (learning motivation) with Y2 (learning outcomes) obtained sig. (2-tailed) $0.028<0.05$ with a correlation coefficient of 0.402 which means that both variables have a positive and significant relationship with a moderate level of closeness. The relationship $\mathrm{X} 1$ (environment as a source of learning), X2 (motivation to learn) with Y1 (interest in learning) obtained sig. (2-tailed) $0,000<0.05$ with a correlation coefficient of 0.922 which means that the three variables have a positive and significant relationship with a very strong level of closeness. The relationship X1 (environment as a source of learning), X2 (motivation to learn) with Y2 (learning outcomes) obtained sig. (2-tailed) $0,000<0.05$ with a correlation coefficient of 0.918 which means that the three variables have a positive and significant relationship with a very strong level of closeness.

Conclusion: The environment as a source of learning and student motivation has a very close relationship in increasing student interest and learning outcomes in the Plant Morphology course at STIKP-IWN Bula.
\end{abstract}

Keywords: Environment, Learning Resources, Learning Motivation, Learning Interest, Learning Outcomes 


\begin{abstract}
Abstrak
Latar Belakang: Belajar biologi dengan memanfaatkan lingkungan sebagai sumber belajar berarti menggunakan pendekatan lingkungan. Pendekatan lingkungan adalah suatu strategi pembelajaran yang dilakukan dengan cara memanfaatkan lingkungan sebagai sumber atau bahan pengajaran. Penelitian ini bertujuan untuk mengetahui hubungan lingkungan sebagai sumber belajar dan motivasi mahasiswa dalam meningkatkan minat dan hasil belajar pada mata kuliah Morfologi Tumbuhan di Sekolah Tinggi Keguruan IImu Pendidikan Ita Wotu Nusa (STKIP-IWN) Bula.
\end{abstract}

Metode: Metode yang digunakan dalam penelitian ini yaitu metode eksperimen semu (Quasi Experiment). Subjek penelitian ini adalah seluruh mahasiswa biologi semester III yang berjumlah 30 Orang. Teknik pengumpulan data dilakukan dengan tes awal, tes akhir dan angket. Teknik analisis data yang digunakan dalam penelitian ini akan dianalisis uji korelasi dengan bantuan program IBM statistic versi 23.0 for windows.

Hasil: Hasil penelitian menunjukan hubungan $\mathrm{X} 1$ (lingkungan sebagai sumber belajar) dengan $\mathrm{Y} 1$ (minat belajar) diperoleh sig.(2-tailed) $0,024<0,05$ dengan nilai correlation coefficient sebesar 0,412 yang berarti kedua variabel memiliki hubungan yang positif dan signifikan dengan tingkat keeratan sedang. Hubungan X1 (lingkungan sebagai sumber belajar) dengan Y2 (hasil belajar) diperoleh nilai nilai sig.(2-tailed) $0,013<0,05$, dengan nilai correlation coefficient sebesar 0,448 yang berarti kedua variabel memiliki hubungan yang positif dan signifikan dengan tingkat keeratan sedang. Hubungan X2 (motivasi belajar) dengan Y1 (minat belajar) sig.(2-tailed) 0,018<0,05 dengan nilai correlation coefficient sebesar 0,430 yang berarti kedua variabel memiliki hubungan yang positif dan signifikan dengan tingkat keeratan sedang. Hubungan X2 (motivasi belajar) dengan Y2 (hasil belajar) diperoleh sig.(2-tailed) $0,028<0,05$ dengan nilai correlation coefficient sebesar 0,402 yang berarti kedua variabel memiliki hubungan yang positif dan signifikan dengan tingkat keeratan sedang. Hubungan X1 (lingkungan sebagai sumber belajar), X2 (motivasi belajar) dengan Y1 (minat belajar) diperoleh nilai sig.(2-tailed) $0,000<0,05$ dengan nilai correlation coefficient sebesar 0,922 yang berarti ketiga variabel memiliki hubungan yang positif dan signifikan dengan tingkat keeratan sangat kuat. Hubungan X1 (lingkungan sebagai sumber belajar), X2 (motivasi belajar) dengan Y2 (hasil belajar) diperoleh nilai sig.(2-tailed) $0,000<0,05$ dengan nilai correlation coefficient sebesar 0,918 yang berarti ketiga variabel memiliki hubungan yang positif dan signifikan dengan tingkat keeratan sangat kuat.

Kesimpulan: Jadi, lingkungan sebagai sumber belajar dan motivasi mahasiswa memiliki hubungan yang sangat erat dalam meningkatkan minat dan hasil belajar mahasiswa pada mata kuliah Morfologi Tumbuhan di STIKP-IWN Bula.

Kata Kunci: Lingkungan, Sumber Belajar, Motivasi Belajar, Minat Belajar, Hasil Belajar

\section{PENDAHULUAN}

Seiring perkembangan dan kemajuan dunia pendidikan, pendidik dituntut untuk selalu meningkatkan kualitas proses pembelajaran, seperti menyelenggarakan kegiatan pembelajaran yang aktif, kreatif, efektif dan menyenangkan sehingga dapat memberikan pengalaman belajar yang berkesan bagi peserta didik. Salah satu faktor yang dapat menunjang keberhasilan proses pembelajaran adalah pemilihan metode pembelajaran yang tepat dan sumber belajar yang mendukung proses pembelajaran. Metode pembelajaran harus disesuaikan dengan kompetensi dasar.

Dalam proses pembelajaran ada dua aspek yang menonjol, yakni metode pembelajaran dan sumber belajar sebagai alat bantu mengajar. Metode adalah teknik atau cara mengajar seorang pendidik dalam menyampaikan dan berinteraksi dengan peserta didik, sehingga proses belajar berjalan dengan baik dan tujuan pembelajaran tercapai. Sementara, Sumber belajar merupakan segala sesuatu yang dapat memberikan kemudahan kepada peserta didik dalam memperoleh sejumlah informasi, pengetahuan dan keterampilan dalam proses belajar mengajar. Pemanfaatan lingkungan diperlukan dalam pembelajaran sebagai sumber dalam memanfaatkan berbagai sumber belajar yang ada di lingkungan belajar dan upaya menjadikan lingkungan kampus sebagai bagaian integral dari masyarakat setempat (Sudjana \& Rivai, 2000).

Lingkungan merupakan segala sesuatu yang terdapat di sekitar anak yang bersifat kebendaan (Saifullah, 2008). Lingkungan merupakan salah satu sumber belajar yang 
dekat dan mudah untuk dimanfaatkan oleh tenaga pendidik, lingkungan adalah contoh nyata dalam sebuah pembelajaran, terutama dalam pembelajaran Sains, lingkungan dapat mengenalkan secara langsung kepada peserta didik mengenai fenomena, bentuk, gerak, sehingga peserta didik memperoleh contoh yang kongkrit dalam proses pembelajaran. Tujuan dari penelitian ini adalah untuk mengetahui Hubungan Lingkungan Sebagai Sumber Belajar dan Motivasi Mahasiswa dalam Meningkatkan Minat dan Hasil Belajar Pada Mata Kuliah Morfologi Tumbuhan di Sekolah Tinggi Keguruan Ilmu Pendidikan Ita Wotu Nusa (STKIP-IWN) Bula.

\section{METODE PENELITIAN}

Penelitian ini dilaksanakan pada tanggal 29 Oktober 2018- 29 Januari 2019. Sedangkan tempat penelitian ini pada STKIP-IWN Bula, kelas Biologi semester III pada mata kuliah Morfologi Tumbuhan. Subjek dalam penelitian ini adalah seluruh mahasiswa biologi semester III yang berjumlah 30 Orang. Variabel yang digunakan dalam penelitian ini adalah variabel bebas (X1) lingkungan sebagai sumber belajar dan (X2) motivasi belajar sedangkan variabel terikat (Y1) minat belajar dan (Y2) hasil belajar. Instrumen dalam penelitian ini adalah berupa alat pengumpul data penelitian yaitu, pre-test dan post-test, kuesioner motivasi belajar, kuesioner minat belajar, dan kuesioner lingkungan sebagai sumber belajar. Teknik analisa data dilihat menggunakan uji korelasi dengan bantuan program IBM statistic versi 23.0 for windows.

\section{HASIL DAN PEMBAHASAN}

\section{A. Uji Prasyarat}

1. Uji Normalitas

Untuk menguji normalitas data pada sampel terdistribusi normal atau tidak, data dianalisis dengan program IBM statistic versi 23.0 for windows dengan kriteria pengambilan keputusan yaitu, signifikansi $>0,05$ maka data berdistribusi normal dan jika signifikansi $<0,05$ maka data tersebut tidak berdistribusi normal.

Tabel 1. Tabel Hasil Uji Normalitas Pre-test dan Post-test

\begin{tabular}{lccr}
\hline \multicolumn{4}{c}{ Chi-Square Tests } \\
\hline & Value & Df & $\begin{array}{c}\text { Asymptotic } \\
\text { Significance (2-sided) }\end{array}$ \\
\hline Pearson Chi-Square & $179,717^{\text {a }}$ & 180 &, 492 \\
\hline Likelihood Ratio & 103,561 & 180 & 1,000 \\
\hline $\begin{array}{l}\text { Linear-by-Linear } \\
\text { Association }\end{array}$ & 10,377 & 1 &, 001 \\
\hline N of Valid Cases & 30 & & \\
\hline $\begin{array}{l}\text { a. 208 cells (100,0\%) have expected count less than 5. The } \\
\text { minimum expected count is ,03. }\end{array}$ & & \\
\hline
\end{tabular}

Berdasarkan Tabel 1. di atas terlihat bahwa data yang dianalisis dengan program IBM statistic versi 23.0 for windows uji normalitas menunjukan nilai signifikansi lebih besar dari nilai $\alpha$ yaitu, 0,492 maka masuk kategori $>0,05$, hal ini berarti data preetest dan posttest di atas adalah berdistribusi normal.

\section{Uji Homogenitas}

Berdasarkan hasil perhitungan uji normalitas hasil tes awal dan tes akhir berdistribusi normal, kemudian dihitung homogenitas pada tes awal dan tes akhir. Uji homogenitas digunakan untuk melihat perbedaan skor mahasiswa. 
Tabel 2. Tabel Hasil Uji Homogenitas X1, X2 dan Y (Pre-test)

\begin{tabular}{lrrrrr}
\hline \multicolumn{5}{c}{ Test of Homogeneity of Variances } \\
\hline & Levene Statistic & df1 & df2 & Sig. \\
\hline Lingkungan & 2,064 & 6 & 14 &, 124 \\
\hline Motivasi & 2,192 & 6 & 14 &, 106 \\
\hline
\end{tabular}

Tabel 2. variabel bebas (X1), (X2), dan variabel terikat $(\mathrm{Y})$, menggunakan program IBM statistic versi 23.0 for windows dengan pengambilan keputusan nila signifikansi lebih besar dari nilai $\alpha$ atau (sig. $>0,05$ ). data yang diperoleh memiliki varians yang homogen, apabila nilai signifikansi lebih kecil dari nilai $\alpha$ atau (sig. $<0,05)$ maka varians data tidak homogen.

Tabel 3. Tabel Hasil Uji Homogenitas X1, X2, dan Y (Post-test)

\begin{tabular}{lrrrrr}
\hline \multicolumn{5}{c}{ Test of Homogeneity of Variances } \\
\hline & Levene Statistic & df1 & df2 & Sig. \\
\hline Lingkungan & 1,507 & 8 & 17 &, 227 \\
\hline Motivasi &, 809 & 8 & 17 &, 604 \\
\hline
\end{tabular}

Berdasarkan hasil uji homogenitas dengan menggunakan program IBM statistic versi 23.0 for windows pada Tabel 3. terlihat bahwa nlai signifikansi lebih besar dari nilai a maka dapat dikatakan data yang diperoleh adalah homogen.

\section{B. Uji Hipotesis}

Uji hipotesis dalam penelitian ini ada dua yaitu, analisis korelasi sederhana (Bivariate Correlations) yang digunakan untuk mengetahui keeratan hubungan antara dua variabel dan untuk mengetahui arah hubungan yang terjadi. Koefisien korelasi sederhana menunjukkan seberapa besar hubungan yang terjadi antara dua variabel, dan analisis korelasi ganda bertujuan untuk melihat seberapa besar hubungan antara variabel bebas $(X)$ dan variabel terikat $(Y)$ secara bersama-sama. Untuk analisis korelasi sederhana dan analisis korelasi ganda data dianalisis menggunakan program IBM statistic versi 23.0 for windows.

Interpretasi koefisien korelasi menurut dapat lihat pada tabel di bawah ini:

Tabel 4. Interpretasi Koefisien Korelasi

\begin{tabular}{cc}
\hline Interval Koefesien & Tingkat Hubungan \\
\hline $0,00-0-199$ & Sangat Rendah \\
\hline $0,20-0,399$ & Rendah \\
\hline $0,40-0,599$ & Sedang \\
\hline $0,60-0,799$ & Kuat \\
\hline $0,80-1,000$ & Sangat Kuat \\
\hline
\end{tabular}

\section{Hipotesis 1}

Hipotesis pertama menyatakan bahwa "Terdapat hubungan antara lingkungan sebagai sumber belajar terhadap minat belajar mahasiswa. Hasil penghitungan hipotesis pertama dengan program IBM statistic versi 23.0 for windows dapat dilihat pada ringkasan hasil analisis korelasi sederhana yang disajikan dalam Tabel 5. 
Tabel 5. Hasil Analisis Korelasi Sederhana X1 dengan Y1

\begin{tabular}{|c|c|c|c|c|}
\hline \multicolumn{5}{|c|}{ Correlations } \\
\hline & & & Lingkungan & Minat \\
\hline \multirow[t]{6}{*}{ Spearman's rho } & Lingkungan & $\begin{array}{l}\text { Correlation } \\
\text { Coefficient }\end{array}$ & 1,000 & , 412* \\
\hline & & Sig. (2-tailed) & & 024 \\
\hline & & $\mathrm{N}$ & 30 & 30 \\
\hline & Minat & $\begin{array}{l}\text { Correlation } \\
\text { Coefficient }\end{array}$ &, $412^{*}$ & 1,000 \\
\hline & & Sig. (2-tailed) & ,024 & \\
\hline & & $\mathrm{N}$ & 30 & 30 \\
\hline
\end{tabular}

Dari tabel output di atas diketahui nilai sig.(2-tailed) antara X1 (lingkungan sebagai sumber belajar), dengan Y1 (minat belajar) adalah $0,024<0,05$, yang berarti terdapat korelasi yang signifikan. Selanjutnya diperoleh nilai correlation coefficient sebesar 0,412 yang berarti kedua variabel memiliki hubungan yang positif dan signifikan dengan tingkat keeratan sedang.. Selanjutnya bahwa hipotesis yang berbunyi "ada hubungan antara lingkungan sebagai sumber belajar terhadap minat belajar mahasiswa pada mata kuliah morfologi tumbuhan di STKIP-IWN Bula" dinyatakan diterima.

\section{Hipotesis 2}

Hipotesis kedua menyatakan bahwa "Terdapat hubungan lingkungan sebagai sumber belajar terhadap hasil belajar mahasiswa pada mata kuliah morfologi tumbuhan di STKIP-IWN Bula". Hasil penghitungan hipotesis kedua dengan program IBM statistic versi 23.0 for windows dapat dilihat pada ringkasan hasil analisis korelasi sederhana hipotesis 2 yang disajikan dalam tabel 6 .

Tabel 6. Hasil Analisis Korelasi Sederhana X1 dengan Y2

\begin{tabular}{|c|c|c|c|c|}
\hline \multicolumn{5}{|c|}{ Correlations } \\
\hline & & & Lingkungan & Hasil \\
\hline \multirow[t]{6}{*}{ Spearman's rho } & Lingkungan & $\begin{array}{l}\text { Correlation } \\
\text { Coefficient }\end{array}$ & 1,000 & , 448* \\
\hline & & Sig. (2-tailed) & &, 013 \\
\hline & & $\mathrm{N}$ & 30 & 30 \\
\hline & Hasil & $\begin{array}{l}\text { Correlation } \\
\text { Coefficient }\end{array}$ & ,448* & 1,000 \\
\hline & & Sig. (2-tailed) & 013 & \\
\hline & & $\mathrm{N}$ & 30 & 30 \\
\hline
\end{tabular}

*. Correlation is significant at the 0.05 level (2-tailed).

Dari tabel output di atas diketahui nilai sig.(2-tailed) antara X1 (lingkungan sebagai sumber belajar), dengan Y2 (hasil belajar) adalah 0,013<0,05, yang berarti terdapat korelasi yang signifikan. Selanjutnya diperoleh nilai correlation coefficient sebesar 0,448 yang berarti kedua variabel memiliki hubungan yang positif dan signifikan dengan tingkat keeratan sedang. Selanjutnya bahwa hipotesis yang berbunyi "ada hubungan antara lingkungan sebagai sumber belajar terhadap hasil belajar mahasiswa dinyatakan diterima.

\section{Hipotesis 3}

Hipotesis ketiga menyatakan bahwa "Terdapat hubungan motivasi terhadap minat belajar mahasiswa pada mata kuliah morfologi tumbuhan di STKIP-IWN Bula". Hasil penghitungan pada ringkasan hasil analisis korelasi sederhana hipotesis 3 yang disajikan dalam Tabel 7. 
Tabel 7. Hasil Analisis Korelasi Sederhana X2 dengan Y1

\begin{tabular}{|c|c|c|c|c|}
\hline \multicolumn{5}{|c|}{ Correlations } \\
\hline & & & Motivasi & Minat \\
\hline \multirow[t]{6}{*}{ Spearman's rho } & Motivasi & $\begin{array}{l}\text { Correlation } \\
\text { Coefficient }\end{array}$ & 1,000 & , 430 \\
\hline & & Sig. (2-tailed) & & 018 \\
\hline & & $\mathrm{N}$ & 30 & 30 \\
\hline & Minat & $\begin{array}{l}\text { Correlation } \\
\text { Coefficient }\end{array}$ & , 430* & 1,000 \\
\hline & & Sig. (2-tailed) & ,018 & \\
\hline & & $\mathrm{N}$ & 30 & 30 \\
\hline
\end{tabular}

Dari tabel output di atas diketahui nilai sig.(2-tailed) antara X2 (Motivasi belajar), dengan $Y 1$ (minat belajar) adalah $0,018<0,05$, yang berarti terdapat korelasi yang signifikan. Selanjutnya diperoleh nilai correlation coefficient sebesar 0,430 yang berarti kedua variabel memiliki hubungan yang positif dan signifikan dengan tingkat keeratan sedang. Selanjutnya bahwa hipotesis yang berbunyi "ada hubungan antara motivasi sebagai sumber belajar terhadap minat belajar mahasiswa pada mata kuliah morfologi tumbuhan di STKIPIWN Bula" dinyatakan diterima.

\section{Hipotesis 4}

Hipotesis keempat menyatakan bahwa "Terdapat hubungan motivasi terhadap hasil belajar mahasiswa pada mata kuliah morfologi tumbuhan di STKIP-IWN Bula". Hasil penghitungan hipotesis keempat dengan program IBM statistic versi 23.0 for windows dapat dilihat pada ringkasan hasil analisis korelasi sederhana hipotesis 4 yang disajikan dalam Tabel 8.

Tabel 8. Hasil Analisis Korelasi Sederhana X2 dengan Y2

\begin{tabular}{|c|c|c|c|c|}
\hline \multicolumn{5}{|c|}{ Correlations } \\
\hline & & & Motivasi & Hasil \\
\hline \multirow[t]{6}{*}{ Spearman's rho } & Motivasi & $\begin{array}{l}\text { Correlation } \\
\text { Coefficient }\end{array}$ & 1,000 & , 402 \\
\hline & & Sig. (2-tailed) & & ,028 \\
\hline & & $\mathrm{N}$ & 30 & 30 \\
\hline & Hasil & $\begin{array}{l}\text { Correlation } \\
\text { Coefficient }\end{array}$ & , 402* & 1,000 \\
\hline & & Sig. (2-tailed) &, 028 & \\
\hline & & $\mathrm{N}$ & 30 & 30 \\
\hline
\end{tabular}

Dari tabel output di atas diketahui nilai sig.(2-tailed) antara X2 (Motivasi belajar), dengan Y1 (minat belajar) adalah $0,028<0,05$, yang berarti terdapat korelasi yang signifikan. Selanjutnya diperoleh nilai correlation coefficient sebesar 0,402 yang berarti kedua variabel memiliki hubungan yang positif dan signifikan dengan tingkat keeratan sedang. Hipotesis yang berbunyi "ada hubungan antara motivasi sebagai sumber belajar terhadap hasil belajar mahasiswa pada mata kuliah morfologi tumbuhan di STKIP-IWN Bula" dinyatakan diterima.

\section{Hipotesis $\mathbf{5}$}

Hipotesis kelima menyatakan bahwa "Terdapat hubungan antara lingkungan sebagai sumber belajar dan motivasi mahasiswa secara bersama-sama dengan minat belajar mahasiswa pada mata kuliah morfologi tumbuhan di STKIP-IWN Bula". Hasil penghitungan hipotesis kelima dengan dapat dilihat pada pada Tabel 9. 
Tabel 9. Hasil Analisis Korelasi Ganda X1, X2 Dengan Y1

\begin{tabular}{|c|c|c|c|c|}
\hline \multicolumn{5}{|c|}{ Correlations } \\
\hline \multicolumn{3}{|c|}{ Control Variables } & Lingkungan & Motivasi \\
\hline \multirow[t]{6}{*}{ Minat } & Lingkungan & Correlation & 1,000 & ,922 \\
\hline & & $\begin{array}{l}\text { Significance (2- } \\
\text { tailed) }\end{array}$ & & ,000 \\
\hline & & Df & 0 & 27 \\
\hline & Motivasi & Correlation & ,922 & 1,000 \\
\hline & & $\begin{array}{l}\text { Significance (2- } \\
\text { tailed) }\end{array}$ & ,000 & \\
\hline & & $\mathrm{Df}$ & 27 & 0 \\
\hline
\end{tabular}

Dari tabel output di atas diketahui nilai sig.(2-tailed) antara X1 (lingkungan sebagai sumber belajar), $\mathrm{X} 2$ (motivasi belajar) dengan $\mathrm{Y} 1$ (minat belajar) adalah $0,000<0,05$, yang berarti terdapat korelasi yang signifikan. Selanjutnya diperoleh nilai correlation coefficient sebesar 0,922 yang berarti ketiga variabel memiliki hubungan yang positif dan signifikan dengan tingkat keeratan sangat kuat. Hipotesis yang berbunyi "ada hubungan antara lingkungan sebagai sumber belajar dan motivasi mahasiswa terhadap minat belajar mahasiswa mata kuliah morfologi tumbuhan di STKIP-IWN Bula" dinyatakan diterima.

\section{Hipotesis 6}

Hipotesis keenam menyatakan bahwa "Terdapat hubungan antara lingkungan sebagai sumber belajar dan motivasi mahasiswa secara bersama-sama dengan hasil belajar mahasiswa pada mata kuliah morfologi tumbuhan di STKIP-IWN Bula" . Uji hipotesis keenam dilakukan dengan analisis korelasi ganda. Hasil penghitungan hipotesis keenam dengan bantuan program IBM statistic versi 23.0 for windows dapat dilihat pada ringkasan hasil analisis korelasi ganda pada Tabel 10 .

Tabel 10. Hasil Analisis Korelasi Ganda X1, X2 dengan Y2

\begin{tabular}{|c|c|c|c|c|}
\hline \multicolumn{5}{|c|}{ Correlations } \\
\hline \multicolumn{3}{|c|}{ Control Variables } & Lingkungan & Motivasi \\
\hline \multirow[t]{6}{*}{ Hasil } & Lingkungan & Correlation & 1,000 & ,918 \\
\hline & & $\begin{array}{l}\text { Significance (2- } \\
\text { tailed) }\end{array}$ & &, 000 \\
\hline & & $\mathrm{Df}$ & 0 & 27 \\
\hline & Motivasi & Correlation & ,918 & 1,000 \\
\hline & & $\begin{array}{l}\text { Significance (2- } \\
\text { tailed) }\end{array}$ & ,000 & \\
\hline & & $\overline{D f}$ & 27 & 0 \\
\hline
\end{tabular}

Dari tabel output di atas diketahui nilai sig.(2tailed) antara X1 (lingkungan sebagai sumber belajar), $\mathrm{X} 2$ (motivasi belajar) dengan $Y 1$ (minat belajar) adalah $0,000<0,05$, yang berarti terdapat korelasi yang signifikan. Selanjutnya diperoleh nilai correlation coefficient sebesar 0,918 yang berarti ketiga variabel memiliki hubungan yang positif dan signifikan dengan tingkat keeratan sangat kuat. Selanjutnya bahwa hipotesis yang berbunyi "ada hubungan antara lingkungan sebagai sumber belajar dan motivasi mahasiswa terhadap hasil belajar mahasiswa pada mata kuliah morfologi tumbuhan di STKIP-IWN Bula" dinyatakan diterima. 


\section{SIMPULAN}

Berdasarkan hasil analisis data dan juga pembahasan yang telah dipaparkan dalam penelitian ini, maka dapat ditarik kesimpulan sebagai berikut:

1) Adanya hubungan positif antara lingkungan sebagai sumber belajar terhadap minat belajar mahasiswa pada mata kuliah morfologi tumbuhan di STKIP-IWN Bula. Hal ini ditunjukan dengan nilai sig.(2-tailed) adalah $0,024<0,05$, yang berarti terdapat korelasi yang signifikan. Selanjutnya diperoleh nilai correlation coefficient sebesar 0,412 yang berarti kedua variabel memiliki hubungan yang positif dan signifikan dengan tingkat keeratan sedang.

2) Adanya hubungan positif antara lingkungan sebagai sumber belajar terhadap hasil belajar mahasiswa pada mata kuliah morfologi tumbuhan di STKIP-IWN Bula. Hal ini ditunjukan dengan sig.(2-tailed) adalah 0,013<0,05, yang berarti terdapat korelasi yang signifikan. Selanjutnya diperoleh nilai correlation coefficient sebesar 0,448 yang berarti kedua variabel memiliki hubungan yang positif dan signifikan dengan tingkat keeratan sedang.

3) Adanya hubungan positif antara motivasi terhadap minat belajar mahasiswa pada mata kuliah morfologi tumbuhan di STKIP-IWN Bula. Hal ini ditunjukan dengan nilai sig.(2-tailed) adalah $0,018<0,05$, yang berarti terdapat korelasi yang signifikan. Selanjutnya diperoleh nilai correlation coefficient sebesar 0,430 yang berarti kedua variabel memiliki hubungan yang positif dan signifikan dengan tingkat keeratan sedang.

4) Adanya hubungan positif motivasi terhadap hasil belajar mahasiswa pada mata kuliah morfologi tumbuhan di STKIP-IWN Bula. Hal ini ditunjukan dengan nilai sig.(2-tailed) adalah $0,028<0,05$, yang berarti morfologi tumbuhan di STKIP-IWN Bula. Hal ini ditunjukan dengan nilai nilai sig.(2-tailed) adalah $0,000<0,05$, yang berarti terdapat korelasi yang signifikan. Nilai correlation coefficient sebesar 0,922 yang berarti ketiga variabel memiliki hubungan yang positif dan signifikan dengan tingkat keeratan sangat kuat.

5) Adanya hubungan positif antara lingkungan terdapat korelasi yang signifikan. Selanjutnya diperoleh nilai correlation coefficient sebesar 0,402 yang berarti kedua variabel memiliki hubungan yang positif dan signifikan dengan tingkat keeratan sedang.

6) Adanya hubungan positif antara lingkungan sebagai sumber belajar dan motivasi mahasiswa terhadap minat belajar mahasiswa pada mata kuliah sebagai sumber belajar dan motivasi mahasiswa terhadap hasil belajar mahasiswa pada mata kuliah morfologi tumbuhan di STKIP-IWN Bula. Hal ini ditunjukan dengan nilai nilai sig.(2-tailed) adalah $0,000<0,05$, yang berarti terdapat korelasi yang signifikan. Nilai correlation coefficient sebesar 0,918 yang berarti ketiga variabel memiliki hubungan yang positif dan signifikan dengan tingkat keeratan sangat kuat.

\section{DAFTAR PUSTAKA}

Djamarah, S. B. 2008. Psikologi Belajar. Edisi 2. Jakarta: Bumi Aksara.

Istialina. 2016. Pemanfaatan lingkungan sebagai sumber belajar pada sub tema Hewan Dan Tumbuhan Di Lingkungan Rumahku kelas IV SD Negeri 3 Jeumpa Kabupaten Bireuen. Jurnal IImiah: vol. I. Ngalim, P. 2012. Prinsip-prinsip dan Teknik Evaluasi Pengajaran. Bandung: Remaja Rosdakarya.

Prahmadita, A. D. 2014. Faktor-faktor Yang Mempengaruhi Minat Siswa Untuk Mengikuti Ekstrakurikuler Drumband di SMP Negeri 1 Sleman. Fakultas Bahasa dan Seni. Yogyakarta: Universitas Negeri Yogyakarta. http://eprints.uny.ac.id/17679/

Saifullah, A. 2008. Pendidikan Pengajaran dan Kebudayaan. Kebudayaan. Surabaya: Usaha Nasional.

Santyasa, I. W. 2007. Landasan Konseptual Media Pembelajaran. Workshop Media Pembelajaran bagi Guru-Guru SMA Negeri Banjar Angkan. Universitas Pendidikan Ganesha. .

Sudjana, N. \& Rivai, A. 2000. Sumber Belajar dan Alat Pelajaran. Jakarta: Bumi Aksara. 
Biopendix, Volume 6, Nomor 2, Pebruari 2020, hlm. 68-76

Susanto, A. 2013. Teori Belajar dan Pembelajaran di Sekolah Dasar. Jakarta: Kencana.

Suprijono, A. 2012. Cooperative Learning : Teori \& Aplikasi PAIKEM. Yogyakarta: Pustaka Pelajar.
Sutrisno, T. D. \& Sugiyono. 2006. Profil Pemanfaatan Media Pembelajaran Dalam Menciptakan Perkuliahan yang Kondusif di Universitas Negeri Malang. Jurnal Pendidikan dan Pembelajaran. 